\title{
FRUCTO SYRUP FROM WHEY MILK VIA BIOTECHNOLOGY
}

\author{
Randa M. Rafeh ${ }^{1}$; M.S. Hikal ${ }^{2}$; A.B. Abdelrazik ${ }^{3}$; Hoida A.M. El-Shazly ${ }^{1}$ \\ and S.H. Ali ${ }^{2}$ \\ 1- Food Technology Research Institute, ARC, Giza, Egypt \\ 2- Agric. Biochemistry Dept., Fac. of Agric., Ain Shams Univ., Cairo, Egypt \\ 3- Genetics Dept., Fac. of Agric., Ain Shams Univ., Cairo, Egypt
}

Keywords: Glucose isomerase, Lactase, Whey milk, Fructose

\section{ABSTRACT}

The present study deal with hydrolysis of lactose by kluyveromyces fragilis that grown in Whey and synthetic medium and the effect of incubated temperature and $\mathrm{pH}$ on enzyme activity Lactase (ß- galactosidase) that hydrolyze lactose in whey milk and synthetic medium .Also the conversion of glucose that released from lactose hydrolysis by kluyveromyces fragilis into fructose via addition of glucose isomerase. The present work showed that the optimum $\mathrm{pH}$ and incubated temperature were $\left(4,35^{\circ} \mathrm{C}\right)$ respectively to optimum enzyme activity Lactase with total glucose reached $60.21 \mathrm{mg} /$ $100 \mathrm{ml}$ in whey medium and $58.61 \mathrm{mg} / 100 \mathrm{ml}$ in synthetic medium after 24 hours. In addition fructose content was $48.15 \mathrm{mg} / 100 \mathrm{ml}$ from released glucose in whey milk that confirmed due to the highest sweet syrup. In conclusion, this study indicated that ability of kluyveromyces fragilis to hydrolyze lactose in natural whey milk higher than synthetic medium.

\section{INTRODUCTION}

Whey is a by-product of the dairy industry, which for years was thought to be insignificant and was either used as an animal feed or it was disposed of as waste. Considering that over 145 million tons of whey is produced worldwide annually, the desire for new methods to utilise whey can be appreciated. Over the last years several studies were carried out concerning the importance of whey is nutritional value and the properties of its ingredients (Silviya R. Macwan et al 2016).

Dairy and cheese industries are an integral part of the food processing industry, producing considerable amounts of liquid discharges, having a high organic load. Whey, the liquid remnant subsequent to the precipitation and removal of milk casein during cheese-making, is a major by-product of dairy and cheese industries (Panesar et al 2007).

The prior hydrolysis of lactose to monosaccharaides significantly increases the options to produce different bio products from whey. Lactose can be hydrolyzed in two ways, either using acid or enzyme. However, acid hydrolysis of lactose gives rise to excessive color formation.

Therefore, enzymatic hydrolysis is more preferred way to carry out the lactose hydrolysis in whey (Burgess\& Shaw, 1983). $\beta$-D-galactosidase (E.C. 3.2.1.23), most commonly known as lactase can be used for the lactose hydrolysis in whey to obtain glucose and galactose (Panesar et al 2006). The hydrolysis of the lactose present in the whey converts the whey into very useful sweet syrup, which can be used in dairy, confectionary, baking and soft drink industry. Thus, it can help to solve the problems related to the use of byproducts from cheese manufacturing industries, avoiding serious pollution problems caused by their disposal (Shukla, 1975; Gekas \& LopezLeiva, 1985). Different yeasts, which are able to utilize lactose can be grown on whey and subsequently be used for $\beta$-D-galactosidase production. The yeasts such as $C$. pseudotropicalis, K. marxianus, $K$. fragilis and $K$. lactis have been used by different researchers for the production of this enzyme from whey-based medium. In most cases, there is need for supplementation of whey with different nutrients for optimal production of the enzyme (Vasiljevic \& Jelen, 2001; Panesar et al 2006; Panesar, 2008; Kumari et al 2011). 
Whey may be widely used in the baking, confectionery, and pastry industries for the production of breads, cakes, cookies, biscuits, crackers, muffins, and icing (Burrington,1999; Ceglińska et al 2007). In addition, whey proteins contain a high level of essential amino acids; they are also considered a source of high quality protein. In addition, they are characterised by a high content of calcium and other minerals, such as potassium and zinc.

Thanks to these properties, whey protein is a valuable additive to bakery products (Burrington, 1999)

Economic progression leads to changes in life style and dietary habits consistent with modern living. Sugars, i.e., mono- and disaccharides, such as glucose, sucrose and lactose are used in various dietary items, with fructose use in human diet increasing several folds in the past 50 years. Fructose occupies about $8 \%$ of every day energy intake by food articles, for example, fruit or fruit products, bakery related items and soft beverages (Park \& Yetley, 1993a). There has been a rising utilization of fructose particularly in beverages that have become almost an essential part of the daily diet (Park \& Yetley, 1993b; Bray et al 2004). Fructose, as compared toglucose, has negligible effects on insulin secretion and does not raise blood glucose level; smaller amounts may even reduce blood glucose (Moore et al 2000) but its utilization is connected with adverse cardiovascular (CV) effects and grave metabolic complications particularly in overweight and obese people (Stanhope et al 2009).

D-Glucose/xylose isomerase (D-xylose ketol isomerase; EC 5.3.1.5), commonly referred to as glucose isomerase (GI), is one of the three highest tonnage value enzymes, amylase and protease being the other two.It catalyzes the reversible isomerization of D-glucose and to D-fructose and isomerization of glucose to fructose is of commercial importance in the production of high-fructose corn syrup (HFCS) (Wiseman ,1975).

The aim of this work is to compare between natural whey milk medium and synthetic medium and evaluate the ability of kluyveromyces fragilis to hydrolyze lactose in natural whey milk compared to synthetic medium. In addition improve the benefit of whey waste to produce sweet fructose from lactose.

\section{MATERIALS AND METHODS}

\section{MATERIALS}

\subsection{Microorganisms}

- Kluveromyces fragilis ATCC 8554, was obtained from Cairo Mircen, Faculty of Agriculture, ASU .

\subsection{Media Used}

Med-1 Cheese whey (was obtained from The Dairy Plant of Agricultural Research Center, Giza, Egypt.) It was used for lactase enzyme and ethanol.

Table 1. Chemical analysis of cheese whey:

\begin{tabular}{|c|c|}
\hline Component & $\%$ \\
\hline Moisture & 89 \\
TSS & 11 \\
Lactose & 4.85 \\
Protein & 0.7 \\
Fat & 0.11 \\
Ash & 0.9 \\
Mg & $1.278 \mathrm{mg} / 100$ \\
$\mathrm{Na}$ & $4.813 \mathrm{ppm}$ \\
$\mathrm{Fe}$ & $0.31 \mathrm{ppm}$ \\
$\mathrm{K}$ & $0.772 \mathrm{ppm}$ \\
$\mathrm{Zn}$ & $0.08 \mathrm{ppm}$ \\
$\mathrm{pH}$ & 5 \\
\hline
\end{tabular}

Cheese whey was boiled for $20 \mathrm{~min}$ and cooled, clear filtrate was obtained by filtering it through muslin cloth. The whey obtained was sterilized by autoclaving at $121^{\circ} \mathrm{C}$ for $15 \mathrm{~min}$ (Gupte and Nair, 2010).

Med-2 Potato Dextrose Agar (PDA) (Difico Manual, 1984)

It was used for growth, propagation and preservation of test yeast. It has the following composition:

$\begin{array}{lc}\text { Potato extract } & 200 \mathrm{~g} \\ \text { Dextrose } & 20 \mathrm{~g} \\ \text { Agar } & 20 \mathrm{~g} \\ \mathrm{PH} & 6\end{array}$

Potato extract was prepared by dissolved potato pieces in one liter of boiling water then filtrated. 
Med-3 Yeast Mold (YM) Broth (Downes and Ito, 2001)

It was used for production of lactase enzyme. It has the following composition (with some modifications) :

$\begin{array}{lc}\text { Approximate Formula* } & \text { Per Liter } \\ \text { Yeast Extract } & 3.0 \mathrm{~g} \\ \text { Malt Extract } & 3.0 \mathrm{~g} \\ \text { Peptone } & 5.0 \mathrm{~g} \\ \text { Lactose } & 48 \mathrm{~g} \\ \text { pH was adjusted to } & 5\end{array}$

1-3- glucose isomerase enzyme EC (5.3.1.5) was obtained from National Company For Maize Products.

\section{2- METHODS}

\section{2-1- Chemical analysis of cheese whey sample}

- Determination of moisture, crude protein, ash, minerals and total fats were determined according to (A.O.A.C. 2007). While lactose was determined according to Duboies et al (1956).

\section{2-2- Hydrolsis of lactose by lactase from Kkluyveromyces fragilis}

Sterile broth medium (100 ml whey medium or synthetic medium) was inoculated with $2 \mathrm{ml}$ inoculum and incubated at different temperature $(30,33$, $35,36,37,38,40)$ for $24,48,72$ hours and determination the enzyme activity. The initial $\mathrm{pH}$ of the whey medium and synthetic medium was 5.0. According to modified method of (Sonia A.DE Bales and Francisco J. Castillo, 1979).

\section{2-3- Enzyme activity}

Enzyme activity was estimated as glucose according to (Lenore Jasewicz and Aaron E. Wasserman, 1960).

2-4- Fructose obtained from addition of glucose isomerase to hydrolyzed whey was 48.15 $\mathrm{mg} / 100 \mathrm{ml}$ and it was determined according to (Park and Yetley, 1993)

\section{2-5- Statistical analysis}

The data were presented as means \pm SD from three replicates and subjected to one way ANOVA. The means of different treatments were compared using Duncan's multiple range test at $p \leq 0.05$. Statistical analyses were performed using SPSS statistical software (IBM SPSS Statistics, version 20) (Snedecor and Cochran, 1980).

\section{RESULTS AND DISCUSSION}

Table 2. Glucose concentration (mg/100ml) released from Whey lactose as affected by lactase activity of kluyveromyces fragilis at different temperatures $\stackrel{\circ}{\circ}(\mathrm{pH}=5)$ during 72 hours.

\begin{tabular}{|c|c|c|c|c|}
\hline $\begin{array}{c}\text { Time/ } \\
\text { tempeture }\end{array}$ & zero & $24 \mathrm{~h}$. & $48 h$ & $72 \mathrm{~h}$ \\
\hline $30^{\circ} \mathrm{C}$ & $\begin{array}{l}5.02^{c} \\
\pm 0.00\end{array}$ & $\begin{array}{l}31.9^{a} \\
\pm 1.90\end{array}$ & $\begin{array}{l}16.52^{\mathrm{D}} \\
\pm 3.10\end{array}$ & $\begin{array}{l}6.06^{\mathrm{C}} \\
\pm 1.52\end{array}$ \\
\hline $33^{\circ} \mathrm{C}$ & $\begin{array}{l}4.65^{c} \\
\pm 0.00\end{array}$ & $\begin{array}{l}56.17^{a} \\
\pm 2.79\end{array}$ & $\begin{array}{l}27.12^{\mathrm{b}} \\
\pm 2.02^{2}\end{array}$ & $\begin{array}{l}6.70^{\mathrm{c}} \\
\pm 6.70\end{array}$ \\
\hline $35^{\circ} \mathrm{C}$ & $\begin{array}{l}6.15^{c} \\
\pm 0.00\end{array}$ & $\begin{array}{l}64.19^{a} \\
\pm 2.34\end{array}$ & $\begin{array}{l}24.92^{b} \\
\pm 2.66\end{array}$ & $\begin{array}{l}9.99^{\mathrm{c}} \\
\pm 1.82\end{array}$ \\
\hline $36^{\circ} \mathrm{C}$ & $\begin{array}{l}7.01^{c} \\
\pm 0.00\end{array}$ & $\begin{array}{l}58.85^{a} \\
\pm 2.83\end{array}$ & $\begin{array}{l}27.63^{\mathrm{b}} \\
\pm 3.09\end{array}$ & $\begin{array}{l}9.64^{c} \\
\pm 0.98\end{array}$ \\
\hline $37^{\circ} \mathrm{C}$ & $\begin{array}{l}4.19^{c} \\
\pm 0.00\end{array}$ & $\begin{array}{l}47.78^{a} \\
\pm 2.61\end{array}$ & $\begin{array}{l}20.21^{\mathrm{b}} \\
\pm 1.37\end{array}$ & $\begin{array}{l}7.38^{c} \\
\pm 0.56\end{array}$ \\
\hline $38^{\circ} \mathrm{C}$ & $\begin{array}{l}5.15^{\mathrm{c}} \\
\pm 0.00\end{array}$ & $\begin{array}{l}40.88^{a} \\
\pm 2.17\end{array}$ & $\begin{array}{l}15.77^{\mathrm{b}} \\
\pm 2.37^{2}\end{array}$ & $\begin{array}{l}3.08^{c} \\
\pm 2.08\end{array}$ \\
\hline $40^{\circ} \mathrm{C}$ & $\begin{array}{l}4.13^{c} \\
\pm 0.00\end{array}$ & $\begin{array}{l}30.03^{a} \\
\pm 2.50\end{array}$ & $\begin{array}{l}13.25^{\mathrm{b}} \\
\pm 2.44\end{array}$ & $\begin{array}{l}0.59^{c} \\
\pm 0.59\end{array}$ \\
\hline
\end{tabular}

The data are presented as means \pm SD from three replicates. Different letters refer to significant differences at $(P \leq 0.05)$.

Data in Table (2) show glucose concentration $(\mathrm{mg} / 100 \mathrm{ml})$ released from Whey lactose as affected by Different temperature at different three periods in hours $(24,48,72)$ as compared by control time (zero time). Data revealed that high glucose concentration resulted in after 24 hours, 48hours and 72 hours respectively with higher concentration found in all incubation temperature after 24 hours compared with 48 hours followed by 72 hours which recorded the lower glucose concentration. These results revealed that the best yield of glucose concentration released from hydrolysis of lactose by lactase of kluyveromyces fragilis could be obtained after 24 hours. On the other hand table (2) also revealed that the highest glucose concentration released from whey lactose was shown at $35^{\circ} \mathrm{C}$ which value $64.19 \mathrm{mg} / 100 \mathrm{ml}$ compared to $31.9,56.17,58.85,47.78,40.88,30.03$ at incubation temperature $30^{\circ} \mathrm{C}, 33^{\circ} \mathrm{C}, 35^{\circ} \mathrm{C}, 36^{\circ} \mathrm{C}, 38^{\circ} \mathrm{C}$, $40^{\circ} \mathrm{C}$ respectively. Generally result revealed that the highest concentration could be result at $35^{\circ} \mathrm{C}$ incubation temperature after 24 hours among all different incubation temperature and. These results clear that the yeast kluyveromyces fragilis firstly hydrolyze lactose in medium throw 24 hours so the glucose content increase significantly after 24 hours then kluyveromyces after 24 hours tend to consume the released glucose in building it is cells 
as source of carbon in order that the concentration significantly showed lower amount after 48 hours and the last value after 72 hours. This results are agree with (Szczodrak J. 2000).

Table 3. Glucose concentration (mg/100ml) released from Synthetic medium lactose as affected by lactase activity of kluyveromyces fragilis at different temperatures ${ }^{\circ} \mathrm{C}(\mathrm{pH}=5)$ during 72 hours

\begin{tabular}{|c|c|c|c|c|}
\hline & $\begin{array}{l}\text { Zero } \\
\text { Time }\end{array}$ & $\begin{array}{c}\text { After24 } \\
\text { hours }\end{array}$ & $\begin{array}{c}\text { After } 48 \\
\text { hours }\end{array}$ & $\begin{array}{c}\text { After } 72 \\
\text { hours }\end{array}$ \\
\hline $30^{\circ} \mathrm{C}$ & $\begin{array}{c}3.01^{c} \pm \\
0.00\end{array}$ & $\begin{array}{c}28.18^{\mathrm{a}} \pm \\
1.14\end{array}$ & $\begin{array}{c}13.06^{\mathrm{b}} \pm \\
2.64\end{array}$ & $\begin{array}{c}1.34^{c} \pm \\
0.89\end{array}$ \\
\hline $33^{\circ} \mathrm{C}$ & $\begin{array}{c}6.17^{\mathrm{c}} \pm \\
0.00\end{array}$ & $\begin{array}{c}57.73^{\mathrm{a}} \pm \\
2.29\end{array}$ & $\begin{array}{c}24.10^{\mathrm{b}} \pm \\
4.19^{\mathrm{b}}\end{array}$ & $\begin{array}{c}5.36^{\mathrm{c}} \pm \\
3.37\end{array}$ \\
\hline $35^{\circ} \mathrm{C}$ & $\begin{array}{c}2.13^{\mathrm{C}} \pm \\
0.00\end{array}$ & $\begin{array}{c}61.75^{\mathrm{a}} \pm \\
4.36\end{array}$ & $\begin{array}{c}22.16^{\mathrm{b}} \pm \\
4.17\end{array}$ & $\begin{array}{c}7.11^{c} \pm \\
2.63\end{array}$ \\
\hline $36^{\circ} \mathrm{C}$ & $\begin{array}{c}3.18^{\mathrm{c}} \pm \\
0.00\end{array}$ & $\begin{array}{c}58.44^{\mathrm{a}} \pm \\
2.71\end{array}$ & $\begin{array}{c}26.00^{\mathrm{b}} \pm \\
4.06\end{array}$ & $\begin{array}{c}10.38^{\mathrm{c}} \pm \\
1.84\end{array}$ \\
\hline $37^{\circ} \mathrm{C}$ & $\begin{array}{c}5.01^{\mathrm{c}} \pm \\
0.00\end{array}$ & $\begin{array}{c}49.50^{\mathrm{a}} \pm \\
3.74\end{array}$ & $\begin{array}{c}26.99^{b} \pm \\
4.06\end{array}$ & $\begin{array}{c}11.15^{\mathrm{c}} \pm \\
0.83\end{array}$ \\
\hline $38^{\circ} \mathrm{C}$ & $\begin{array}{c}2.81^{\mathrm{c}} \pm \\
0.00\end{array}$ & $\begin{array}{c}40.69^{\mathrm{a}} \pm \\
1.39\end{array}$ & $\begin{array}{c}16.88^{b} \pm \\
3.20\end{array}$ & $\begin{array}{c}6.29^{\mathrm{c}} \pm \\
3.15\end{array}$ \\
\hline $40^{\circ} \mathrm{C}$ & $\begin{array}{c}4.94^{\mathrm{c}} \pm \\
0.00\end{array}$ & $\begin{array}{c}28.39^{\mathrm{a}} \pm \\
1.74\end{array}$ & $\begin{array}{c}10.23^{b} \pm \\
1.30\end{array}$ & $\begin{array}{c}0.36^{d} \pm \\
0.36\end{array}$ \\
\hline
\end{tabular}

The data are presented as means \pm SD from three replicates. Different letters refer to significant differences at $(P \leq 0.05)$.

Data in Table (3) show glucose concentration $(\mathrm{mg} / 100 \mathrm{ml})$ released from Synthetic medium lactose as affected by Different temperature at different three periods in hours $(24,48,72)$ as compared by control time (zero time). Data revealed that increased glucose concentration resulted in after 24 hours, 48 hours and 72 hours respectively compared with control. The highest $h$ concentration found in all incubation temperature after 24 hours compared with 48 hours followed by 72 hours. These results revealed that the highest yield of glucose concentration released from hydrolysis of lactose by lactase of kluyveromyces fragilis could be obtained after 24 hours. On the other hand Table (3) also revealed that the highest glucose concentration released from Synthetic medium lactose was observed at $35^{\circ} \mathrm{C}$ which value $61.75 \mathrm{mg} / 100 \mathrm{ml}$ compared to $28.18,57.73,58.44$, $49.50,40.69,28.39$ at incubation temperature $30^{\circ} \mathrm{C}, 33^{\circ} \mathrm{C}, 35^{\circ} \mathrm{C}, 36^{\circ} \mathrm{C}, 38^{\circ} \mathrm{C}, 40^{\circ} \mathrm{C}$ respectively . Generally result revealed that the best concentration could be result at $37^{\circ} \mathrm{C}$ incubation temperature after 24 hours among all different incubation temperature and incubation hours. These results clear that the yeast kluyveromyces fragilis firstly hydrolyze lactose in medium throw 24 hours so the glucose content increase significantly after 24 hours then kluyveromyces after 24 hours tend to consume the released glucose in building it is cells as source of carbon in order that the concentration significantly showed lower amount after 48 hours and the last value after 72 hours in all data obtained.

Table 4. Glucose concentration $(\mathrm{mg} / 100 \mathrm{ml})$ released from whey lactose as affected by lactase activity of kluyveromyces fragilis at $\left(35^{\circ} \mathrm{C}\right.$ and different $\mathrm{pH}$ ) during 72 hours.

\begin{tabular}{|c|c|c|c|c|}
\hline & $\begin{array}{l}\text { Zero } \\
\text { Time }\end{array}$ & $\begin{array}{c}\text { After24 } \\
\text { hours }\end{array}$ & $\begin{array}{c}\text { After } 48 \\
\text { hours }\end{array}$ & $\begin{array}{c}\text { After } 72 \\
\text { hours }\end{array}$ \\
\hline $\mathrm{pH}=6$ & $5.95^{c} \pm$ & $44.43^{a} \pm$ & $19.11^{\mathrm{b}} \pm$ & $4.08^{c} \pm$ \\
\hline $\mathrm{pH}=4$ & $\begin{array}{c}0.00 \\
7.95^{c} \pm\end{array}$ & $\begin{array}{c}2.88 \\
60.21^{\mathrm{a}} \pm\end{array}$ & $\begin{array}{c}1.54 \\
26.39^{b} \pm\end{array}$ & $\begin{array}{c}2.13 \\
7.54^{\mathrm{c}} \pm \\
.95\end{array}$ \\
\hline $\mathrm{pH}=3$ & $6.02^{c} \pm$ & & & $\begin{array}{c}2.00^{c} \\
8.87^{\circ} \pm\end{array}$ \\
\hline $\mathrm{PH}=$ & $\begin{array}{c}0.00 \\
{ }^{c} \\
4.06^{ \pm} \\
0.00\end{array}$ & $\begin{array}{c}3.72^{\mathrm{a}} \\
31.12^{\mathrm{a}} \pm \\
1.05\end{array}$ & $\begin{array}{c}3.42 \\
\text { b } \\
12.71^{ \pm} \pm \\
2.44\end{array}$ & $\begin{array}{c}1.37 \\
1.72^{\mathrm{c}} \pm \\
1.72\end{array}$ \\
\hline
\end{tabular}

The data are presented as means \pm SD from three replicates. Different letters refer to significant differences at $(P \leq 0.05)$.

Data in Table (4) show that glucose concentration $(\mathrm{mg} / 100 \mathrm{ml})$ released from whey lactose affected by different $\mathrm{pH}(2,3,4,6)$ and different incubation time $(0,24,48,72)$ at the best incubation temperature $35^{\circ} \mathrm{C}$ which obtained from the previous study (Table 2). Results from Table (4) show that $\mathrm{pH}$ effect on glucose released from lactose hydrolysis by lactase from kluyveromyces fragilis. It is observed from data in Table (4) that $\mathrm{pH} 4$ was the best $\mathrm{pH}$ among the other $\mathrm{pH}(2,3,6)$. Also at this $\mathrm{pH}$ the incubation time was the highest glucose concentration after 24 hours with value 60.21 $\mathrm{mg} / 100 \mathrm{ml}$ whey medium. Data also show that glucose concentration was decreased after 48 hours, 72 hours of incubation time compared with 24 hours in all $\mathrm{pH}$ studied $(2,3,4,6)$. These results clear that the optimum $\mathrm{pH}$ to obtain high yield of glucose from lactose could be adjusted at $\mathrm{pH} 4$ and after 24 hours of incubation time. This results in agreement with (Sonawat et al 1980). 
Table 5. Glucose concentration $(\mathrm{mg} / 100 \mathrm{ml})$ released from synthetic medium lactose as affected by lactase activity of kluyveromyces fragilis at $\left(35^{\circ} \mathrm{C}\right.$ and different $\left.\mathrm{PH}\right)$ during 72 hours

\begin{tabular}{|c|c|c|c|c|}
\hline & $\begin{array}{l}\text { Zero } \\
\text { Time }\end{array}$ & $\begin{array}{c}\text { After24 } \\
\text { hours }\end{array}$ & $\begin{array}{c}\text { After } 48 \\
\text { hours }\end{array}$ & $\begin{array}{c}\text { After } 72 \\
\text { hours }\end{array}$ \\
\hline $\mathrm{pH}=6$ & $2.19^{c} \pm$ & $46.04^{a} \pm$ & $22.11^{b} \pm$ & $3.09^{c} \pm$ \\
\hline $\mathrm{pH}=4$ & $\begin{array}{c}0.00 \\
4.95^{c} \pm\end{array}$ & $\begin{array}{c}4.56 \\
58.61^{a} \pm\end{array}$ & $\begin{array}{c}2.36 \\
24.10^{b} \pm\end{array}$ & $\begin{array}{c}1.52 \\
5.31^{c} \pm\end{array}$ \\
\hline $\mathrm{pH}=3$ & $\begin{array}{c}0.00 \\
{ }^{\mathrm{c}} \\
7.87^{ \pm}\end{array}$ & $\begin{array}{c}1.45 \\
38.40^{\mathrm{a}} \pm\end{array}$ & $\begin{array}{c}4.10^{b} \\
21.24^{\mathrm{b}} \pm\end{array}$ & $\begin{array}{c}2.74 \\
\mathrm{c} \\
7.77^{ \pm}\end{array}$ \\
\hline $\mathrm{PH}=2$ & $\begin{array}{c}0.00 \\
6.19^{\mathrm{c}} \pm \\
0.00\end{array}$ & $\begin{array}{c}3.24 \\
{ }^{a} \\
26.77^{ \pm} \pm \\
2.38\end{array}$ & $\begin{array}{c}2.90 \\
\text { b } \\
11.07^{ \pm} \\
1.49\end{array}$ & $\begin{array}{c}2.45^{d} \\
0.77^{ \pm} \\
0.77\end{array}$ \\
\hline
\end{tabular}

The data are presented as means \pm SD from three replicates. Different letters refer to significant differences at $(P \leq 0.05)$.

Data in Table (5) show that glucose concentration $(\mathrm{mg} / 100 \mathrm{ml})$ released from synthetic medium lactose affected by different $\mathrm{pH}(2,3,4,6)$ and different incubation time $(0,24,48,72)$ at the best incubation temperature $35 \stackrel{\circ}{\circ}$ which obtained from the previous study (Table 3 ). Results from table (5) show that $\mathrm{pH}$ effect on glucose released from lactose hydrolysis by lactase from kluyveromyces fragilis. It is observed from data in Table (5) that $\mathrm{pH} 4$ was the best $\mathrm{pH}$ among the other $\mathrm{pH}(2,4$, $6)$. Also at this $\mathrm{pH}$ the incubation time was the best after 24 hours with value $58.61 \mathrm{mg} / 100 \mathrm{ml}$ synthetic medium. Data also show that glucose concentration was decreased after 48, 72 hours of incubation time compared with 24 hours in all pH study $(2,3,4,6)$. These results clear that the optimum $\mathrm{pH}$ to obtain high yield of glucose from lactose could be adjusted at $\mathrm{pH} 4$ and after 24 hours of incubation time.

\section{REFERENCES}

A.O.A.C. 2007. Official Methods of Analysis. $17^{\text {th }}$ edn., Washington, DC: Association of official Analytical Chemists, Inc. USA.

Bray, G.A., Nielsen, S.J. and Popkin, B.M. 2004. Consumption of high-fructose corn syrup in beverages may play a role in the epidemic of obesity. Am. J. Clin. Nutr., 79, 537-543.

Burgess, K. and Shaw, M. 1983. Dairy. In: Godfrey T, Reichlet J, eds. Industrial Enzymology, Surrey, England: Mcmillan Publishers Ltd, pp. 221-259.
Burrington, K. 1999. Whey products in baked goods. U.S. Dairy Export Council, Application monographs. Bakery, pp. 1-8. Available at: [http://pdf.thepdfportal.net/PDFFiles/61842.pdf].

Ceglińska, A., Pluta, A., Skrzypek J., Krawczyk, P. 2007. Study on the application of nanofi Itrated whey-derived mineral components in the production of bread. Zywnosc. Nauka. Technologia. Jakosc, 6(55), 234-241.

Difico Manual, 1984. Dehydrate culture media and reagent for microbiology. 10th Ed. DIFCO. Laboratories, Detroit, U.S.A. pp. 15-23.

Duboies, M., Gilles, K.A., Hamilton, J., Rebers, P.A. and Smith, F. 1956. Colorimetric method for determination of related substances. Anal. Chem., 28, 250-352.

Downes, F.P. and Ito, K. 2001. Compendium of Methods for the microbiological examination of foods, $4^{\text {th }}$ ed., APHA Inc. Washington DC., pp. 37-39.

Gekas, V. and Lopez-Leiva M. 1985. Hydrolysis of lactose: A literature review. Process Biochem 20, 2-12.

Gupta, A. and Nair, J. 2010. B-Galactosidase production and ethanol fermentation from whey using Kluveromuces marxianus NCIM 3551. J. of Scientific and Indust. Research. 69, 855859.

Kumari, S., Panesar, P.S. and Panesar R. 2011. Production of $\beta$-galactosidase using novel yeast isolate from whey. Intl J. Dairy Sci., 6, 150-156.

Lenore Jasewicz, Aaron E. Wasserman, 1960. Quantitative determination of lactase. Eastern Regional Research Laboratory. pp. 393-400.

Moore, C.M., Cherrington, D.A., Mann, L.S. and Davis, N.S. 2000. Acute fructose administration decreases the glycemic response to an oral glucose tolerance test in normal adults. J. Clin. Endocrinol. Metab., 85, 4515-4519.

Park, Y.K. and Yetley, E.A. 1993/ Intakes and food sources of fructose in the United States. American J. of Clinical Nutrition, 58, 737S747S.

Panesar, P.S., Kennedy, J.F., Gandhi, D.N. and Bunko, K. 2007. Bioutilisation of whey for lactic acid production. Food Chem 105(1), 1-14.

Panesar, P.S., Panesar, R., Singh, R.S., Kennedy, J.F. 2006. Microbial production, immobilization and applications of $\beta$-D-galactosidase. J. Chemical Technol Biotechnol 81, 530-543.

Panesar, P.S. 2008. Production of $\beta$-Dglactosidase from whey using Kluyveromyces marxianus. Research J Microbiol 3, 24-29. 
Park, Y.K. and Yetley, E.A. 1993. Intakes and food sources of fructose in the United States. Am. J. Clin. Nutr., 58, 737-747.

Shukla, T.P. 1975. Beta-galactosidase technology: A solution to the lactose problem. Crit. Rev. Food Technol 5, 325-356.

Silviya, R. Macwan, Bhumika K. Dabhi, Parmar, S.C. and Aparnathi, K.D. 2016. Whey and its Utilization. Int. J. Curr. Microbiol. App. Sci 5(8), 134-155.

Snedecor, G.M. and Cochran, W.G. 1980. Statistical methods, Sixth Edition, lowa State Univ. press, Amer. Lowa, USA.

Sonawat, H.M., Agrwal, A. and Dutta, S.M. 1980. Production Of B-Galactosidase from kluveromyces fragilis Grown on Whey. Folia Microbial. 26, 370 -376.

Sonia, A.D.E. Bales, Francisco J. Castillo, 1979. Production of Lactase by Candida pseudotropicalis Grown in Whey. Applied and Environmental Microbiology, pp. 1201-1205.

Stanhope, K.L., Schwarz, J.M., Keim, N.L., Griffen, S.C., Bremer, A.A., Graham, J.L.,
Hatcher, B., Cox, C.L., Dyachenko, A., Zhang, W., McGahan, J.P., Seibert, A., Krauss, R.M., Chiu, S., Schaefer, E.J., Ai, M., Otokozawa, S., Nakajima, K., Nakano, T., Beysen, C., Hellerstein, M.K., Berglund, L. and Havel, P.J. 2009. Consuming fructosesweetened, not glucose-sweetened, beverages increases visceral adiposity and lipids and decreases insulin sensitivity in overweight/obese humans. J. Clin. Invest, 119, 1322-1334.

Szczodrak, J. 2000. Hydrolysis of lactose in whey permeate by immobilized b-galactosidase from Kluyleromyces fragilis. Journal of Molecular Catalysis B: Enzymatic 10, 631-637.

Vasiljevic, T. and Jelen, P. 2001. Production of 0-galactosidase for lactose hydrolysis in milk and dairy products using thermophilic lactic acid bacteria. Innov Food Sci Emerg Technol 2, 75-85.

Wiseman, A. 1975. Handbook of enzyme biotechnology. Ellis Horwood Ltd., Chichester, United Kingdom. 26, 885-893. 